\title{
BRAND SWITCHING BEHAVIOR FROM SAMSUNG TO OPPO AMONG MILLENIALS
}

\author{
Dikdik Harjadi ${ }^{1}$, Sifa Nurfatimah ${ }^{2}$ \\ dikdik.harjadi@uniku.ac.id \\ Universitas Kuningan \\ Jl. Cut Nyak Dhien No.36A, Cijoho, Kec. Kuningan, Kabupaten Kuningan, Jawa Barat
}

received: 2/11/20; revised: 5/6/21; approved: 28/6/21

\begin{abstract}
Along with the proliferation of smartphone manufacturers, the latest innovations and fascinating features are presented, such as selfie cameras, VOOCflash charge (the best fast charging) on their products, providing that selfie cameras accommodate people who love to upload their photos to social media. Nowadays, consumers' needs have called attention to a lifestyle that requires them to make choices on goods or services that are compatible with their needs. This study employed a survey method, with samples comprising millennials in Kuningan Regency with a total of 283 respondents, in which the data collection was done using questionnaires, validity and reliability tests were conducted. Multiple linear regression was used in data analysis. The results showed that product features, lifestyle, and price had a positive and significant effect simultaneously and partially on brand switching decisions. However, price had a greater influence on consumers' decisions to switch brands.
\end{abstract}

Keywords: product feature; lifestyle; price; brand switching; millennials

\section{INTRODUCTION}

The development of today's technology is rapid and dynamic. Along with it, emerges the consumers' growing needs and desires for technology. Currently, people's need for smartphones is so high that it has penetrated all age groups from children to elderly. In Indonesia, the need for mobile phones is very high. This can be seen from the fact that almost all groups of people use mobile phones to fulfill their needs for communication, providing that smartphones are products harnessed with modern and innovative technology.

The majority of people use a smartphone for its versatility; sending and receiving e-mails, chatting, photoediting, browsing the Internet, online shopping, as well as a social media that is now commonly used by the public to obtain information. Mobile phones or smartphones have now become an inseparable part of people's lifestyles, with many smartphone manufacturers, such as Apple, Samsung, OPPO, Xiaomi, Asus, Lenovo, Vivo, Coolpad, and many more, aiming their own target market.

With the current extensive use of smartphones, many manufacturers release their products, resulting in a competition between one another in meeting the public's demands. On that account, companies should work optimally to maintain, appeal, and get more consumers so that they will be loyal to the products they manufacture.

Along with the proliferation of smartphone manufacturers, the latest innovations and fascinating features are presented, such as selfie cameras, VOOC flash Charge (the best fast charging) on their products, providing that selfie cameras accommodate people who love to upload their photos to social media. Nowadays, consumers' needs have called attention to a lifestyle that requires them to make choices on goods or services that are compatible with their needs. Lifestyles is part of consumers' behavior that affect their decisions in making a purchase (Sari, et al. 2013; Sloot \& Verhoef, 2008).

Samsung is the most popular mobile phone, used by people ranging from the middle to the upper class. Samsung was the first that released a smartphone, however in 2014 to 2016 , there was a fall in sales, as much as $27.8 \%$ in 2014, $24.8 \%$ in 2015, and 22.2\% in 2016. However, there was an increase by $26.1 \%$ in 2017 (Trendforce, 2017).

OPPO is one of the new mobile phone brands released in 2014, and today it has become a superior product because it brings out the latest and fascinating features compared to Samsung smartphones. According to Trendforce data (2017), in 2015 OPPO smartphones ranked the 8th with a percentage of $3.8 \%$, and in the following year it progressed with a constant surge as much as of 3.9\%, until in 2017 it reached $8.1 \%$. 
Brand switching is a current interesting phenomenon in which this behavior often occurs to smartphone users for various reasons. Sharma, et al. (2017), Kumar \& Chaarlas (2011), and Koech, et al. (2018), specifically define brand switching as a transition in purchasing process that is characterized by the changes from one brand to another or from one product to another in the same category. Meanwhile, according to Grigoriou, et al. (2018); Anjana (2018), and Dhevika, et al. (2013), brand switching done by consumers during the time of using products reflects the extent of the consumers' loyalty. It can be concluded that brand switching is the termination of a consumer's relationship with a certain service provider by stopping purchase transactions and commencing a relationship with a new one in a permanent or a temporary fashion (Ashfaq \& Samreen, 2015; Appiah, et al. 2019; Saeed \& Azmi, 2014). This implies that the consumers may decide to terminate the relationship with the service provider for several reasons. Boote (1998) suggests that consumers' brand switching behavior is their decision to stop their purchase transactions either permanently or temporarily.

Many suggest that one of the reasons Samsung smartphone consumers switched to OPPO smartphone was due to their lifestyle (Kumar \& Chaarlas, 2011; Sharma, et al., 2017; Malasi, 2012). For instance, among teenagers in both high school and university, keep an eye on the advances of OPPO smartphones, so that OPPO releases their new products with up-to-date features, ranging from attractive colors and design that is wide and thin in dimension, attracting millennials to switch brand.

Brand switching is likely to ensue due to a progressively dynamic lifestyle. Today, a smartphone functions beyond just a means of communication, it has become part of one's lifestyle. Lifestyle refers to the habituated behavior of an individual consumer that has become part of life necessities. Fintikasari \& Ardyan (2018) explain that lifestyle can be identified by how people spend their time, what is important for people in regards to the environment, and what people think about themselves and their surroundings. Meanwhile, Mowen and Minor (2002) concluded that lifestyle is a way of life, spend money, and allocate time. Lifestyle is a person's rhythm of life expressed in activities, interests, opinions, spending money, and allocating time. Lifestyle describes the person "as a whole" in interacting with the environment. Similarly, Adnyana \& Seminari (2018) define lifestyle as a way that can describe a person's behavior, including how she/he lives, spend their money and make use of the time they have. Lifestyle can be concluded as a visible characteristic of a person, which describes their system of value, as well as attitudes towards his/herself and the environment. Lifestyle can also be a factor in brand switching decisions for a product (Al-Kwifi \& Ahmed, 2015; Korry \& Suartini, 2018). Therefore, if the smartphone has a major influence on the value of the consumer's lifestyle, it will be less likely to for them to switch brands and vice versa. Consequently, the brands must create products that can meet and accommodate the lifestyle of their consumers.

The millennials construct a community that is sensitive to technological developments, they have the tendency to switch smartphone brands as time passes to support their need for the latest technology, as well as part of a lifestyle (Bolton, et al., 2013; Valentine \& Power, 2013). Consumers' decisions in choosing smartphones are also inseparable from the product features offered by manufacturers. Features are an absolute requirement that must be embedded in smartphones, for features can also be the identity of the product itself (Dewantara, et al. 2018; Wijaya, 2014; Malasi, 2012). Various product features potentially make the consumers satisfied and their needs met by these products. According to Kotler \& Keller, (2009), product features also function as a competitor's tools to distinguish a product from other similar products. Products manufactured by a company must offer an assortment of product features. The more fascinating these features are, while also considered to be able to meet consumers' needs, the less likely it is for the consumers to switch brands and vice versa. For this reason, companies must provide features that meet consumers' needs so that they are satisfied with the products.

According to Sari (2014), features are aspects of performance that are useful for enhancing basic functions, in relation to product choices and development. Product features are often represented by the innovations made by the company. Ashfaq \& Samreen (2015), and Appiah, et al. (2019) stated that innovation is believed to be an effort to improve market performance of a product. Innovations through the addition of the latest and unique features can appeal consumers as well as distinguish them from competitors' products. The slow technological advance in features that are important to users can increase the likelihood of brand switching (Al-Kwifi \& McNaughton, 2013), resulting in market share loss and deducted profits.

Features are elements of a product that are viewed important by the consumers that serve as the basis for making a purchase decision (Tjiptono, 2002). In addition, Koech, et al. (2018); Al-Kwifi and Ahmed (2015) mention these elements include product details such as features, design, and quality. Many products can be offered with a variety of features that complement their basic functions (Kotler and Keller, 2009). These said features must be different from those offered by competing products. Moreover, Al-Kwifi, et al. (2014) found that the design of a product with varied features and high performance tends to cause consumers to switch brands. 
Additionally, the consumers' considerations do not only lay on features, but also on the price. Products with relatively affordable price that are offered with good quality can increase the consumers' buying interest. Price often becomes a consumer's consideration, although it may also be due to other factors. For companies, pricing must go through a number of considerations, be it the competitors' prices and the value added in the quality of the product itself. According to Kotler and Armstrong (2010), price is the amount of money charged for a product or service, or the amount of value that consumers exchange for the benefits of having or using a product or service. Al-Kwifi and McNaughton (2013) suggest that price has a domineering effect than other factors in brand switching behavior. Aaker in Tjiptono (2002) argues that brand switching behavior is likely to happen due to internal and external factors. One of the external factors is a factor that comes from the outside, for example a discount or a lower price. According to Tjiptono and Candra (2012), price can be defined as the amount of money (monetary unit) or other aspects (non-monetary) that contain certain uses needed in exchange of a product. Price is a factor in external attributes that determines consumers' perceptions regarding the product quality.

\section{METHODS}

This study employs descriptive and verification methods. Descriptive method is used in a study conducted to determine independent variables, either one or more variables without making comparisons or relations with other variables. Meanwhile, verification method is a method that aims to mathematically test a hypothesis regarding the correlation between variables from the problem investigated, it is safe to say that it is a method to test the accuracy of a hypothesis.

The operations of variables in this study can be explained as follows: (1) Features are elements of a product that are viewed important by the consumers that serve as the basis for making a purchase decision (Tjiptono, 2002). The indicators used to measure product features are the extensive applications, the suitability of the features with the consumers' needs, and accessibility; (2) Lifestyle is a way to describe people's behavior, including how they live, use their money, and make use of their (Sumarwan, 2002). The indicators used to measure lifestyle are needs, brand trust, and pride; (3)Price can be defined as the amount of money (monetary unit) or other aspects (non-monetary) that contain certain uses needed in exchange of a product (Tjiptono \& Candra, 2012). The indicators used to measure the price were price comparisons with other brands, price-benefit comparisons, price-quality suitability; and (4) Brand switching is a purchase pattern characterized by a change or switch from one brand to another (Ervina \& Ridwan, 2016). The indicators used were the consumers' dissatisfaction with the previous brand, the decision not to use the previous brand anymore, the decision to accelerate to stop using brand currently in use.

The population of this study comprised the millennials who were born between 1982 and 2002 who previously used Samsung smartphones and switched to OPPO. The exact number of the population in the study was unknown. Therefore, the researcher determined the sample size based on Lameshow formula. A total of 300 samples was selected, but after distributing the questionnaires, only 283 were returned and thoroughly filled in. Accidental sampling was employed for data collection in this study. Data was obtained through questionnaires using an interval scale of 1-10, which was previously tested for validity and reliability. Furthermore, the data analysis method used in this study is multiple linear regression analysis.

\section{RESULTS}

The statistical results of normality test showed that all levels of significance in the variables of study were normally distributed with no multicollinearity. The results of the regression analysis are shown in Table 1.

Table 1. Regression Estimation

Coefficients $^{\mathrm{a}}$

\begin{tabular}{|c|c|c|c|c|c|c|}
\hline \multirow[b]{2}{*}{ Model } & & \multicolumn{2}{|c|}{ Unstandardized Coefficients } & \multirow{2}{*}{$\begin{array}{c}\text { Standardized Coefficients } \\
\text { Beta }\end{array}$} & \multirow[b]{2}{*}{$\mathrm{t}$} & \multirow[b]{2}{*}{ Sig. } \\
\hline & & $\mathrm{B}$ & Std. Error & & & \\
\hline \multirow[t]{4}{*}{1} & (Constant) & 5.740 & 1.589 & & 3.612 & .000 \\
\hline & Product feature & .153 & .061 & .150 & 2.517 & .012 \\
\hline & Lifestyle & .157 & .055 & .150 & 2.835 & .005 \\
\hline & Price & .401 & .066 & .360 & 6.090 & .000 \\
\hline
\end{tabular}

a. Dependent Variable: Brand Switching

Source: Data processed (2018) 
From the result of calculation, it can be seen that the regression equation obtained is:

$$
\mathrm{Y}=5.740+0.153 \mathrm{X}_{1}+0.157 \mathrm{X}_{2}+0.401 \mathrm{X}_{3}
$$

From the result of calculation, it can be concluded that the regression coefficient of price is greater than the products' features and lifestyle. As the results of the simultaneous test are shown in Table 2, and the partial test in Table 3.

\begin{tabular}{llccccc}
\multicolumn{7}{c}{$\begin{array}{c}\text { Table 2. F Test } \\
\text { ANOVA }^{\mathrm{b}}\end{array}$} \\
\hline Model & & Sum of Squares & df & Mean Square & F & Sig. \\
\hline 1 & Regression & 1379.986 & 3 & 459.995 & 30.665 & $.000^{\mathrm{a}}$ \\
& Residual & 4185.145 & 279 & 15.001 & & \\
& Total & 5565.131 & 282 & & & \\
\hline
\end{tabular}

a. Predictors: (Constant), Price, Lifestyle, Product Features

b. Dependent Variable: Brand Switching

Source: Data processed (2018)

\section{DISCUSSIONS}

Based on the results of data analysis that examines the effect of product features, lifestyle and price on brand switching, it was found that these variables could predict the switch from Samsung smartphones to OPPO among millennials in Kuningan Regency. This shows that if product features, lifestyle and prices increase, it will increase brand switching. This indicated that the increase in product features, lifestyle and prices will also it will also increase the likelihood of brand switching. It can be concluded that the transfer of Samsung smartphone users to OPPO was determined by product features, lifestyle and price factors. From multiple regression analysis, it was acquired that price was the variable with the greatest influence compared to product features and lifestyle. This was indicated by the regression coefficient of price as much as 0.401 . The findings of this study supported those of previous studies conducted by Anjana (2018), Grigoriou, et al. (2018), Koech, et al. (2018), Dhevika, et al. (2013), and Adnyana \& Seminari (2018).

The results of this study also show that product features had a positive effect on brand switching. It implies that the more extensive and attractive features provided by a smartphone brand will attract consumers to switch to that brand. Brand owners are certainly fully aware of this particular fact, that smartphone products they offered must be able to follow and meet the demands of consumer needs that continue to grow, particularly Generation $\mathrm{Y}$ who was born and living in the midst of advanced technological developments like today, resulting in high demands for new innovations. This finding supports the results of a study conducted by Wijaya, (2014) which examines the effect of product attributes on brand switching, in which product features have a positive and significant effect on brand switching decisions. These results are in line with those of Appiah, et al. (2019), Dewantara, et al. (2018), Sari, et al. (2014) and Koech, et al. (2018), and Adnyana \& Seminari (2018).

Furthermore, another finding of this study also shows that lifestyle had a positive effect on brand switching among Generation Y. This implies that an increase in one's lifestyle will stimulate the drive to switch brands. This finding supports the results of previous studies conducted by Wijaya, (2014), Fintikasari \& Ardyan (2018), Ashfaq \& Samreen (2015) and Adnyana \& Seminari (2018) suggesting the same aftermath that lifestyle had a positive effect on brand switching. Moreover, these findings indicate that companies must continue to pay close attention to patterns of behavior and lifestyles happening in society, especially Generation $\mathrm{Y}$, a generation that is already highly dependent on smartphones to use social media as one of their primary needs. Lifestyle behavior patterns that continue to change can be an opportunity for companies to seize existing market share.

This study also shows something rather noteworthy where it turns out that the price has the greatest influence of the three variables studied, surpassing product features and lifestyle. This suggests that price has a positive influence on brand switching, implying that the higher the price, the more likely it gets for consumers to switch brands. In fact, from this study it can be concluded that consumers who switch brands are mainly influenced by the price factor. This finding is in line with the results of studies conducted by Saeed \& Azmi, (2014), Grigoriou, et al. (2018), Guo, et al. (2021), Yen, et al. (2013), and Dhevika, et al. (2013) which suggest the same finding in which price has a positive and significant effect on brand switching. These findings are lessons for brand owners that in the midst of smartphone competitions, it appears that some consumers think very rationally; they will tend to choose products with lower prices but with extensive features. OPPO with its latest types of smartphones offer lower prices than Samsung, although in terms of product features, design, packaging and quality, they are considerably equal. 


\section{CONCLUSIONS}

The conclusion obtained in this study is that product features, lifestyle and price simultaneously and partially had a positive and significant effect on the brand switching from Samsung to OPPO. However, price has the greatest influence. The millennials are very concerned about price prior to making brand switching decisions. Product features and quality improvement of OPPO smartphones offered as an attempt to meet the consumers' expectations are spot-on, resulting in consumers' satisfaction that leads to loyalty to the product. On the other hand, lifestyle did not have a significant influence in brand switching behavior.

\section{REFERENCES}

Adnyana, I. P. W. and Seminari, N. K. 2018. Pengaruh Lifestyle, Efek Komunitas dan Fitur Produk Terhadap Brand Switching Warung Internet ke Wifi Id Corner (Studi pada Wifi Id Corner di Denpasar). INOBIS: Jurnal Inovasi Bisnis dan Manajemen Indonesia, 1(2), pp.158-171.

Al-Kwifi, O. S. and Ahmed, Z. U. 2015. An Intellectual Journey into The Historical Evolution of Marketing Research in Brand Switching Behavior-Past, Present and Future. Journal of Management History.

Al-Kwifi, S. O. and McNaughton, R. B. 2013. The Influence of Product features on Brand Switching: The Case of Magnetic Resonance Imaging Equipment. Journal of Business \& Industrial Marketing.

Al-Kwifi, O. S., Ahmed, Z. U., \& Yammout, D. 2014. Brand Switching of High-Technology Capital Products: How Product Features Dictate the Switching Decision. Journal of Product \& Brand Management, 23(4/5), 322-332

Anjana, S. S. 2018. A Study on Factors Influencing Cosmetic Buying Behavior of Consumers. International Journal of Pure and Applied Mathematics, 118(9), pp.453-459.

Appiah, D., Howell, K. E. Ozuem, W. and Lancaster, G., 2019. Building Resistance to Brand Switching During Disruptions in a Competitive Market. Journal of Retailing and Consumer Ser-vices, 50, pp.249-257.

Ashfaq, H. and Samreen, L. 2015. Factors Leading to Brand Switching in Cellular phones: A case of Pakistan. Journal of Marketing and Consumer Research, 17(10), pp.32-40.

Bolton, R. N., Parasuraman, A., Hoefnagels, A., Migchels, N., Kabadayi, S., Gruber, T., Loureiro, Y. K. and Solnet, D., 2013. Understanding Generation Y and Their Use of Social Media: A Review and Research Agenda. Journal of Service Management.

Boote, J. 1998. Towards a Comprehensive Taxonomy and Model of Consumer Complaining Behaviour. Journal of Consumer Satisfaction, Dissatisfaction and Complaining Behavior, 11, pp.140-151.

Dewantara, S., Mursito, B. and Kustiyah, E. 2018. Analisis Faktor Ketidakpuasan, Fitur Produk, Harga, Dan Word of Mouth Terhadap Brand Switching Pada Produk Smartphone Oppo. Jurnal Ekonomi dan Kewirausahaan, 18(1).

Dhevika, V. P. T., Latasri, O. T. V. and Maruthamuthu, S. 2013. A Study on Brand Switching Among Cellular Network Service Users in Tiruchirappalli. International Journal of Marketing and Technology, 3(9), p.160.

Ervina, K. W. dan Ridwan, B. 2016. Pengaruh Atribut Produk, Harga, Kebutuhan Mencari Variasi dan Ketidakpuasan Konsumen Terhadap Keputusan Perpindahan Merek dari Blackberry ke Smartphone Samsung Galaxy di Purworejo. E-journal, Vol. 12, No. 1B, Hal: 1-13.

Fintikasari, I. and Ardyan, E. 2018. Brand Switching Behaviour in The Generation Y: Empirical Studies on Smartphone Users. Jurnal Manajemen dan Kewirausahaan (Journal of Management and Entrepreneurship), 20(1), pp.23-30.

Grigoriou, N., Majumdar,A. and Lie, L. 2018. Drivers of Brand Switching Behavior in Mobile Telecommunications. Athens Journal of Mass Media and Communications, 4(1), pp.7-28.

Guo, J., Shan, S., Wang, Y. and Khan, Y. A. 2021. Analyzing Chinese Customers' Switching Intention of Smartphone Brands: Integrating the Push-Pull-Mooring Framework. Discrete Dy-namics in Nature and Society, 2021.

Koech, J.K., Cheruiyot, P., Cheruiyot, J. 2018. Effect of Product Features on Brand Switching of Tea by Consumers in Kericho Town, Kenya. Int. J. Econ. Commer. Manag. VI, 280-289.

Korry, P. D. P. and Suartini, N. W. 2018. Influencing Factor on Brand Switching Behaviour Between Millennial and X Generation in Mobile Phone Market. International Research Journal of Management, IT and Social Sciences, 5(6), pp.80-92.

Kotler, P. and Armstrong, G., 2010. Principles of marketing. Pearson education.

Kotler, P. and Keller, K. L. 2009. Manajemen Pemasaran, Edisi Ke-13, Jilid 1 dan Jilid 2. Penerbit Erlangga, Jakarta. 
Kumar, R. R. and Chaarlas, D. L. 2011. Brand Switching in Cellular Phone Service Industry Because of BillRelated Issues Faced by Clients. International Journal of Event Management Re-search, 1(5), pp.30-42.

Malasi, J. M. 2012. Influence of Product Attributes on Mobile Phone Preference Among University Students: A Case of Undergraduate Students. International Journal of Academic Research in Economics and Management Sciences, 1(6), p.10.

Mowen, John C. and Minor, M. 2002. Perilaku Konsumen. Penerjemah: Dwi Kartini Yahya. Edisi Ke-5 Jilid 2. Jakarta: Erlangga.

Sari, D. P., Hidayat, W. and Widiartanto, W. 2014. Pengaruh Lifestyle, Efek Komunitas Dan Fitur Produk Terhadap Keputusan Brand Switching Smartphone Blackberry Ke Merek Lain. Jurnal Ilmu Administrasi Bisnis, 3(4), pp.233-241.

Saeed, M. and Azmi, I. B. A. G. 2014. Religion and Brand Switching Behaviour of Muslim Consumers. Middle East J Sci Res, 21(9), pp.1611-1617.

Sharma, M. S. B., Sharma, G. and Diwan, R., 2017. Factors Affecting Brand Switching Behavior \& Brand Preferences Towards Mobile Phones in Punjab. People, 3(1).

Sloot, L. M. and Verhoef, P. C. 2008. The Impact of Brand Delisting on Store Switching and Brand Switching Intentions. Journal of Retailing, 84(3), pp.281-296.

Tjiptono, F. 2002. Manajemen Jasa. Yogyakarta: Penerbit Andi.

Tjiptono, F. \& Candra, G. 2012. Pemasaran Strategik. Yogyakarta: CV. Andi Offset. Edisi Kedua.

Valentine, D. B. \& Power, T. L. 2013. Generation Y Values and Lifestyle Segments. Journal of Consumer Marketing, 30(7), 597-606.

Wijaya, Y. S. 2014. Pengaruh Atribut Produk Terhadap Keputusan Perpindahan Merek (Survei pada Mahasiswa Fakultas Ilmu Administrasi Angkatan 2011/2012 Universitas Brawijaya yang Beralih Merek ke Smartphone Samsung). Jurnal Administrasi Bisnis, 12(2).

Yen, T. F., Hsiou-hsiang, J. L. and Chen, Y. C. 2013. The Moderating Effects of Switching Costs on SatisfactionCommitment Relationship: An Agritourism Approach in Taiwan. International Journal of Organizational Innovation, 5(3). 